\section{Links for Chemists}

www.liv.ac.uk/Chemistry/Links/links.html

Uma lista impressionante de cerca de 8500 links de Química da responsabilidade do Departamento de Química da Universidade de Liverpool. Fundado em Junho de 1995, tornou-se rapidamente num dos mais populares sites sobre Química. Desde Novembro de 2000 é a secção de Química da WWW Virtual Library (www.vlib.org), considerada a colecção de sites mais antiga da web. Organizado em várias secções, universidades, indústria, literatura, informação, emprego, organizaçōes, software, por exemplo, a sua consulta é extremamente simples e os resultados são, geralmente, de grande qualidade, graças ao trabalho de constante actualização.

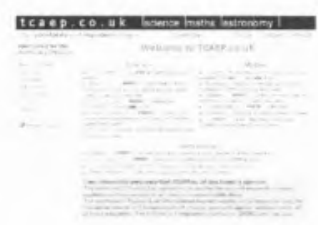

\section{The Constants and Equations Page}

tcaep.co.uk/

Tendo começado por ser um projecto apenas com o objectivo de listar o maior número possivel de constantes e equações, o site foi crescendo e o seu criador, Jonathan Stott, acrescentou-Ihe tanta, e tão útil, informação que o seu título é extremamente redutor. Dividido em três secções principais - ciência, matemática e astronomia - é possível, para além de equações e constantes, encontrar, na secção de ciência, uma tabela periódica muito completa, vários conversores, uma lista de unidades SI e uma lista de símbolos mais comuns. Uma das caracteristicas mais importantes é a facilidade oferecida pelo autor de se poder descarregar todo o site para o nosso computador de modo a consultá-lo off-line (o único inconveniente é que o ficheiro apresenta um tamanho assinalável: cerca de $21 \mathrm{MB}$ ).

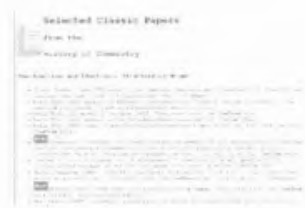

\section{Selected Classic Papers from the History of Chemistry}

webserver.lemoyne.edu/faculty/giunta/ papers1.html

Uma selecção, em duas partes, que reúne alguns dos trabalhos pioneiros mais marcantes da História da Química. Para além da descrição do trabalho, muitas vezes é apresentada também uma breve nota biográfica do seu autor. Para aqueles que se interessam pela História da Química recomenda-se, também, uma visita ao site (webserver. lemoyne.edu/faculty/giunta/index.html) onde esta lista se insere, da responsabilidade de Carmen Giunta, do departamento de Química do Le Moyne College. Encontra-se aí um interessantíssimo conjunto de recursos relacionados com a História da Química, incluindo uma referência a outros sites sobre esta temática. Digno de nota é também o glossário de termos antigos, muitos deles citados nos artigos acima referenciados.

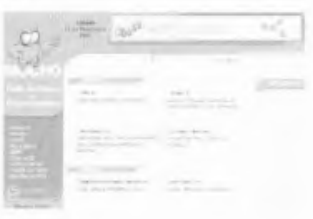

\section{0 mocho}

www.mocho.pt

0 mocho é, desde há muito, considerado como um símbolo de sabedoria. É por isso feliz a sua escolha para designar um Portal de Ciência e Cultura Cientifica. Da responsabilidade do Centro de Física Computacional da Universidade de Coimbra, este portal encontra-se dividido basicamente em duas secçōes principais: ciências e ensino. Para além de bastantes referências a sites internacionais, destaca alguns portugueses muito interessantes. Pode-se, por exemplo, encontrar uma tabela periódica, um roteiro de ciência, um site de software educativo e aquilo que é designado por Molecularium, um site de simulações moleculares muito interessante. Hoje em dia estão identificadas cerca de 145 espécies de mochos. Em Coimbra, trabalha-se, e bem, para criar mais uma...

\section{ISI HighlyCited}

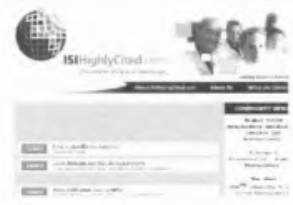
isihighlycited.com

O ISI, Institue for Scientific Information, é bem conhecido por, através dos seus produtos, ter desenvolvido métodos de classificação com base no número de citações que um determinado artigo recebe. Ainda que seja polémico, este método tem-se estabelecido como um dos principais critérios para aferir a qualidade de um determinado trabalho. 0 ISI decidiu dar um passo em frente e elaborou rankings dos autores mais citados, entre 1981 e 1999, em várias áreas cientificas, entre as quais a Química. Neste site pode-se pesquisar por autor, por área, por nome, por instituição ou por país. Para cada autor referido é possível aceder a nota biográfica extremamente detalhada. Este projecto encontra-se em desenvolvimento e pretende, no futuro, listar os 250 cientistas mais citados em cada uma das áreas científicas consideradas.

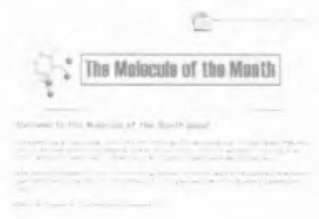

\section{The Molecule of the Month}

origin.ch.ic.ac.uk/motm/

A escolha da molécula do mês é o mote de uma série de sites, a maior parte dos quais são aqui referidos. É uma temática muito popular entre os apaixonados por Química. Este site, mantido por Paul May, da Universidade de Bristol (já aqui referido a propósito de um outro site: Molecules with Silly or Unusual Names), é um bom exemplo do que é possivel encontrar neste tipo de sites. Normalmente, para visualizar as moléculas são necessários vários programas (o autor apresenta uma lista exaustiva do software necessário), mas aqui, em muitos casos, estes não são necessários. Algumas moléculas seleccionadas são ainda acompanhadas de uma breve resenha histórica. Para os interessados, o autor aceita sugestões para molécula do mês mas vai avisando que a lista de espera vai em 2-3 meses...

Jorge Marques Gonçalves jgoncalv@fc.up.pt 